\title{
IJELTAL
}

\section{Politeness Strategy in Shanghai Knights Film}

\author{
Ernovilinda \\ Universitas Airlangga, Surabaya, Indonesia \\ e-mail:ernovilinda.s.s-2019@fib.unair.ac.id
}

\begin{abstract}
:
Language is a communication tool for every human being and is used to convey ideas, messages, intentions, feelings, opinions to others or even to meet daily needs. Intercultural communication is a communication that frequently occurs in the community. Pragmatics is a branch of linguistics that discusses aspects of language as a communication tool. When combined with culture, intercultural communication that occurs in society can be understood. In order for a speaker's language to be accepted in a society, he needs to fully understand the rules that apply in that society, including an understanding of the appropriate use of certain language functions or speech acts. There is a close relationship between pragmatics and the concept of politeness. Politeness is fundamental in pragmatics because this is a universal phenomenon in the use of language in social contexts. The focus of this research is to identify the politeness strategies used by the two main characters in the Shanghai Knights film, Chon Wang and Roy O'Bannon, and analyze them in terms of the cultural background of the two main characters. This is a qualitative descriptive study. The results show that the politeness strategy used is strongly influenced by their cultural background. The strategy used most often is the bald-on record strategy while the Off-record politenses strategy is the strategy that is the least used by the two main characters of the film. This suggests that an understanding of politeness strategies is needed to realize face-threatening actions (FTA). In other words, politeness strategies are used to maintain continuity and success in communicating.
\end{abstract}

Keywords: Cross-cultural pragmatics, politeness strategy, Shanghai Knights 


\section{Introduction}

Language is a communication tool between community members in the form of sound symbols produced by human speech tools (Keraf, 1997, p. 1). Syamsuddin (1996, p. 2) states that language is a clear sign of a good or bad personality, a clear sign of family and nation, a clear sign of humanity. Thus, language is a communication tool used by humans to convey ideas, messages, intentions, feelings and opinions to others. Every human being has a different "computer" in his brain so they cannot produce the same utterances. Different backgrounds produce clear marks on the language used.

Language is bound by cultural elements. Some opinions state that the relationship of language and culture is a subordinate relationship in which language is under the scope of culture. However, other opinions state that language and culture has an equal relationship with the same position which is called the coordinative relationship. Masinambouw (1985) states that language and culture are two systems that are "attached" to humans because culture is a system that regulates human interaction, while language or culture is a system that functions as a means of sustainability the facility (cited in Chaer, 1995, p. 217-218). Therefore, language and culture are two different sides of a coin, but cannot be separated because language is a reflection of the culture and the identity of the speaker.

Hofstede (2001) stated that when people from different cultures communicate is the time when intercultural communication occurs. Heryadi \& Silvana (2013) reaffirm that "when communication occurs between people of different nationalities, racial groups, or language communities, the communication is intercultural communication." (p. 97). Intercultural communication is the process of exchanging thoughts and meanings between people from different cultures. This definition implies that intercultural communication may deter people from maintaining aspects of their cultural characteristics when it occurs. Intercultural communication is an interaction between people from different cultural backgrounds which might influenced or be influenced by own cultural characteristics.

Pragmatics is a branch of linguistics that studies languages as a communication tool. According to Yule $(1996$, p. 3) pragmatics is the study of the meaning of language in certain contexts, i.e social context of language speakers. The social context includes what is worth saying, how to say it, when to say it, and how to make the language used by others acceptable. In order for a speaker's language to be accepted in a society, one needs to fully understand the rules that apply in that society, including the appropriate use of certain language functions or speech acts. There is a close relationship between pragmatics and the concept of politeness. The most influential theory of politeness is formulated by Brown and Levinson (1987) that politeness is fundamental in pragmatics as it is a universal phenomenon in the use of language in social contexts. The focus of the politeness theory of Brown and Levinson is the concept of face with the term "saving face" with the aim to save the face of the speaker and interlocutor.

Brown and Levinson (1987, p. 60) identified four politeness strategies or general behavioral patterns that speakers can apply including (1) Bald-on Record Strategy (without strategy); (2) Positive politeness strategy; (3) Negative politeness strategy; (4) Off-record politeness strategy (indirect or disguised strategy). This suggests that an understanding of 
politeness strategies is needed to realize face-threatening actions (FTA). Politeness strategy is used to maintain the continuity and success of someone in communication.

Politeness theory is very closely related to culture. When combined, we can learn intercultural communication from pragmatic perspective. The author conducts research on politeness strategies used by the two main characters in the film Shanghai Knights, Chon Wang (Jackie Chan) and Roy O'Bannon (Owen Wilson). Shanghai Knights is the sequel to the film Shanghai Noon. This is an action, adventure and comedy film released in 2003. It was directed by David Dobkin and was nominated in several awards, such as the MTV Awards and Teen Awards as the Choice Movie Fight/Action Sequence. The film was chosen because of some politeness strategies used by the two main characters of the film and the film blends Chinese and Baart (American) culture.

The focus of this research is to identify the politeness strategies used by the two main characters in the Shanghai Knights movie and analyze them in terms of the cultural background of the two main characters. It should be recognized that the two main characters in this film have different backgrounds. Chon Wang (Jackie Chan) has a Chinese cultural background and Roy O'Bannon (Owen Wilson) has a Western (American) cultural background.

A number of studies (Aryanto, 2014; Fitriah. \& Hidayat, 2018; Lucky Nur Safitri et al., 2015; Mu, 2015; Mustiari et al., 2017; Pradnyani et al., 2017; Pratiwi et al., 2018; Retnowaty, 2015; Sari et al., 2017; Selfia \& Marlina, 2016; Supriyanta et al., 2017; Suryani Christina, 2018; Ulfa, 2019) have been conducted on the use of politeness strategies by Brown \& Levinson (1987). First illuminated with the idea of "face-saving view", politeness issues have been further explored in many different contexts. All of the studies above proved that politeness has important roles in communication. However, there are two articles that are quite closely related to my article, they are Rosari (2016) and Aditiawarman \& Elba (2018). Rosari (2016, pp. 19-33) focuses on the use of politeness strategies by the characters in The Great Debaters movie and the factors affecting the characters' politeness in speaking. The analysis is based on Brown and Levinson's politeness strategies and Spolsky's factors affecting someone's politeness in speaking. In her result, she found that all types of politeness strategies proposed by Brown and Levinson are applied and the factors which affecting the usage of the strategies are language style, register and domain, and slang and solidarity. Aditiawarman \& Elba (2018, pp. 32-38) investigate the use of politeness proposed by Brown and Levinson in The Chronicles of Narnia movie. They analyze more in describing the way and the function of the politeness strategies used in the movie. They found out that the function of politeness strategies in the movie are generally to save (one's) face while communicating.

The two articles mentioned above only focus on the use of politeness strategies and the functions or the factors affecting the usage without doing cross cultural analysis. In my article, the analysis is not only identifying types of politeness strategy used and the way they delivered, but also involving the cultural background of the characters. How the cultural background of the characters in Shanghai Knight film affects the use of politeness strategies. Moreover the investigation will show the use of politeness strategies as the results of speakers' culture. 


\section{Theoritical framework}

\subsection{Pragmatics}

Levinson (1983, pp. 21-24) defines pragmatics as follows; first, gragmatics is the study of the relationship between language and context that is basic to an account of language understanding. This shows that in order to understand the meaning of one's language, speakers are required to not only know the meaning of words and grammatical relationships between words, but also draw conclusions from what is assumed. Second, Pragmatics is the study of the ability of language users to pair sentences with the contexts in which they would be appropriate. This second definition emphasizes the importance of compatibility between sentences spoken by speakers of the language with the existing context.

Two pragmatic aspects that need to be examined are the use of language and the context of language speakers. Language speakers need to understand the rules of language use because each language has its own rules that distinguish one language from another and a context. One context in question is the social context that influences the use of language. The use of appropriate language in social context is very closely related to politeness. The use of politeness in language does not only involve the language aspect but also includes the social and cultural values of a speech community.

\subsection{Politeness Theory}

Brown and Levinson (1987, p. 60) identified four politeness strategies or general behavioral patterns that speakers can apply, they are (1) Bald-on Record Strategy (without strategy); (2) Positive politeness strategy; (3) Negative politeness strategy (4) Off-record politeness strategy (indirect or disguised strategy) and explained as follows:

\subsubsection{Bald-on Record Strategy}

This strategy is in accordance with the principle of efficiency in communication as outlined in Grice maxim (Grice 1975 in Brown \& Levinson, 1987, p. 94). With this strategy the speaker does not make any effort to minimize the threat to the face of the speaker or to reduce the consequences of actions that threaten the face (FTA). This can make the interlocutor feel shocked, embarrassed and uncomfortable. This is frequently used by speakers and interlocutors who have know each other well, for example between friends or between family members.

Example: "Get the book for me!"

\subsubsection{Positive politeness strategy}

This strategy is used to show intimacy to interlocutors who are not close to the speaker. To facilitate the interaction, the speaker tries to give the impression of the same fate and as if he has the same desire as the interlocutor and is considered as a shared desire that is truly desired together. This is aimed directly at the positive face of the speaker so that the wish of the speaker is considered a shared desire between the speaker and the speaker and functions as an expedite of social relations with others. By using it, the speaker shows that he wants to be more familiar with the interlocutor. This strategy seeks to minimize the distance between the speaker and the interlocutor by expressing attention and friendship. Thus, the speaker minimizes the FTA. 
A positive politeness strategy is expressed in fifteen ways or actions:

- focus on the other person,

- give more attention, give recognition or sympathy to the interlocutor,

- intensify the attention of the interlocutor,

- use group familiarity markers,

- find a deal,

- avoid conflict,

- equate assumptions into public opinion

- make a joke

- add or agree the opinions of the interlocutors,

- offer help or promise,

- be optimistic,

- involve speakers and interlocutors in activities,

- give or ask for certain reasons,

- assume or displays the similarity of actions.

\subsubsection{Negative politeness strategy}

A negative politeness strategy is an action taken to make up for the negative face of the speaker and the desire of the speaker to be free from the burden with the intention that the actions and intent are not disturbed and not constrained. This action is the basis of valuing behavior, which is also found in positive politeness strategies. The difference is that this strategy is more specific and more focused because the speaker displays supporting functions to minimize certain burdens as something that cannot be avoided by the interlocutor. The main focus of using this strategy is to assume that the speaker is most likely to put a burden or disturbance on the speaker because he has entered the opponent's area of speech. It is assumed that there are certain social distances or certain obstacles in the situation.

This politeness strategy is expressed with the following ten actions:

- state indirectly,

- ask questions or dodging,

- being pessimistic,

- reduce the burden of requests,

- self-humility

- apologize,

- personalize the speaker and interlocutor,

- put face threatening actions as generally accepted rules,

- nominalization,

- states clearly that the actions of the interlocutor are very valuable to the speaker.

\subsubsection{Off-record politeness strategy}

This strategy is expressed in a disguised way and does not represent a clear communicative purpose. This strategy is contrary to the Grice maxim, i.e the relevance maxim, the maximum quantity, the maximum quality, and the regularity maxim. 
Brown and Levinson (1987) add that the more serious an action is, the more strategies the speaker chooses. However, it is not right that one politeness strategy is better than another strategy. A strategy will be polite if used appropriately adjusted to the context of a particular interaction. Furthermore, Brown and Levinson (1987) assert that the weight of an action is formed from the additional value of three dependent variables in society such as: relative $P$, i.e the power of the speaker with the speaker, $D$, i.e social distance between the speaker and the speaker, and $\mathrm{R}$, i.e the degree or ranking of impositions of the action. The assumption underlying this formula is that there is a parallel relationship between the seriousness of the FTA and the values shown by each of these variables. For example, the greater the social distance between the speaker and the speaker or the heavier the burden of the action directed at the opponent, the more polite the strategy is expressed.

\subsection{Cross-Cultural Pragmatic}

Wierzbicka (2003, p. 25) stated, "Different culture, different languages, different speech acts." The statement refers to a cross-cultural pragmatic study, that everyone who has a different cultural background will have a different language and a different speech act. It can be said that, in communication between people of different cultures, for example between ethnic groups, ethnicities, races and social classes, speakers and interlocutors must be able to understand their cultural background. Thus, the greater the cultural differences that exist, the greater the communication process we will run effectively. Communication is very dynamic, so to realize effective communication, the speaker and the interlocutor must understand the cultural background they have.

\subsection{Politeness of Chinese Culture and Western Culture (America)}

In China, the study of politeness began seriously in the '8os. One of the driving figures is Prof. Yueguo Gu from Beijing Foreign Studies University (Tian \& Zhao, 2006, p. 76). In his studies of the modesty of modern Chinese society, Gu found a modesty model that was relevant to Chinese culture. In connection with the concept of politeness, Gu did not see anything related to individual psychological desires, but rather views it in relation to social norms. Politeness is not instrumental, but rather normative. Chinese culture prioritizes the harmony of society above individual freedom. A person's behavior will be meaningful in his community when there is participation from others. This is where the ego is removed and togetherness/unity in a harmony is built (Eelen, 2001, p. 11). Furthermore, as stated by Gu for Chinese people, the principle of politeness is considered as an agreed belief that one's behavior needs to be adjusted to the expectations of respect, simplicity, warmth of attitude, and subtlety of language. Family values are also highly valued in Chinese culture. Therefore, respect for the family is very important. It is also reflected that in Chinese culture, people are a bit more closed and not easy to express something.

Whereas Leech (2007, p. 201) tends to claim that the concept of advance in the context of Western politeness tends to be individualistic and egalitarian motives. Western politeness is not related to the level of social hierarchy and the norms that surround it. Western nations are expressed in politeness by considering various factors such as higher weighting for wise behavior (acts of respecting speech partners) and self-humility (coercion of wills is better considered). Western culture emphasizes the ability of individuals and how individuals play a role in a society. Therefore Westerners can express themselves more openly than Chinese. 
Differences in Chinese and Western culture inspired the author to study the use of politeness strategies of the two main characters in Shanghai Knights movie.

\subsection{About the movie}

\subsubsection{Synopsis}

This movie tells about an adventure of Chon and Roy who are trying to find Chon's father's killer. When Chon's father was killed, the killer also succeeded in seizing the precious seal of the Genghis Khan Dynasty and brought it to England. They leave finally finding the murderer of Chon's father who apparently also tried to steal the throne of the British Empire. They succeed in thwarting the evil plan and find a stamp from the Genghis Khan Dynasty with the help of Lin (Chon's younger sister), Charlie and Artie. They also got the national title from the Queen of England and returned the Genghis Khan Dynasty seal to China.

\subsubsection{Place and time settings}

The background of the movie are China, America and England with the majority of scenes is England. This illustrates England in 1887 when it underwent a massive expansion. England under the leadership of Queen Victoria underwent a period of social, economic and technological change to become a superpower. Victorian era of leadership was the peak of the Industrial Revolution in England. One sign of British glory shown in the film is the machine gun that Chon's father's killer used to kill Queen Victoria to seize her throne.

\subsubsection{Main Character}

\section{Chon Wang (Jackie Chan)}

Chon Wang is played by Jackie Chan who is also the producer of this film. Chon in this film is portrayed as a kind-hearted, honest, loyal friend and so innocent that he is often lied to by his good friend Roy. Chon has martial arts skills that often do scenes that invite laughter when fighting. Chon is unable to express himself.

\section{Roy O'Bannon (Owen Wilson)}

Roy, played by Owen Wilson, is a good friend of Chon. He is described as a character who likes to seduce women and has a lot of experience with women in a negative connotation. You could say Roy is a playboy. In contrast to Chon, Roy is very expressive and very confident.

\section{Research Methodology}

This research is limited to the study of politeness strategies used by the two main characters in the Shanghai Knights movie and analyzes them in terms of the cultural background of the two main characters.

This study uses a qualitative approach in which all data are analyzed using a theory that has been explained in the theoretical foundation. No data is analyzed using a specific formula or calculation.

\subsection{Data collection technique}

The data collected comes from dialogues from the film Shanghai Knights. The first thing the writer does is watch the film. Second, download scenarios that contain movie 
dialogues from the internet. Third, mark the utterances that have politeness strategies in them. Finally, analyzing the data that has been obtained.

Below are the steps of data collection performed by the author:

1. Watched the movie.

2. Matched the scenarios downloaded from the internet with the dialogue in the film.

3. Marked the scenarios that use politeness strategies.

\subsection{Data analysis technique}

According to Miles and Huberman (1994, pp. 10-11), there are three important components in conducting data analysis including data reduction, data display and conclusion drawing. The steps taken by the author to do the analysis are: 1) Data reduction; eliminating unnecessary scenarios without reducing important information needed, 2) Present data for analysis descriptively, and 3) Draw conclusions from existing analyzes.

\section{Findings}

The two main characters in the film Shanghai Knights, Chon Wang (CW) and Roy O'Bannon (RO) use all the politeness strategies that were conceived by Brown and Levinson (1987). The data obtained is presented in the following table:

Table 1. Politeness strategy distribution

\begin{tabular}{|l|c|c|}
\hline \multirow{2}{*}{ Politeness Strategy } & \multicolumn{2}{|c|}{ Total } \\
\cline { 2 - 3 } & CW & RO \\
\hline Bald-on Record Strategy & 11 & 35 \\
\hline Positive Politeness Strategy & - & - \\
\hline - focus attention on oneself & 1 & 6 \\
\hline - give more attention, give recognition or sympathy to the & 5 & 14 \\
\hline - interlocutor & & \\
\hline - intensify attention to the interlocutor & 1 & 4 \\
\hline - find an agreement & 2 & 6 \\
\hline - avoid conflict & 5 & 8 \\
\hline - equate assumptions into public opinion & 1 & 4 \\
\hline - make a joke & 0 & 1 \\
\hline - add or agree with the opinions of the interlocutors & 0 & 2 \\
\hline - offer help or an appointment & 1 & 0 \\
\hline - be optimistic & 2 & 2 \\
\hline - involve speakers and interlocutors in the activity & 4 & 7 \\
\hline - give or ask for a specific reason & 2 & 4 \\
\hline - assume or display similarity in actions & 8 & 5 \\
\hline Negative Politeness Strategy & 1 & 0 \\
\hline - stated indirectly & - & - \\
\hline - ask questions or dodging & 1 & 0 \\
\hline - being pessimistic & 1 & 2 \\
\hline
\end{tabular}


Politeness Strategy In Shanghai Knights Film

\begin{tabular}{|l|c|c|}
\hline - reduce the burden of demand & 0 & 2 \\
\hline - self-humility & 2 & 6 \\
\hline - - pelogize & 2 & 1 \\
\hline - place threatening actions as generally accepted rules & 0 & 1 \\
\hline - nominalization & 0 & 2 \\
\hline - $\begin{array}{l}\text { states clearly that the actions of the interlocutor are very } \\
\text { valuable to the speaker }\end{array}$ & 2 & 0 \\
\hline Off-Record Politeness Strategy & $\mathbf{7}$ & $\mathbf{5}$ \\
\hline Total & $\mathbf{6 1}$ & $\mathbf{1 2 0}$ \\
\hline
\end{tabular}

From the table above, the most frequently used politeness strategy by Chon Wang $(\mathrm{CW})$ is bald-on record strategy (11) followed by giving or asking for a specific reason (8), offrecord politeness strategy (7), giving gifts (6) and giving more attention, giving recognition or sympathy to the interlocutor and finding agreement (5), respectively. This is followed by an optimistic strategy (4). Using group intimacy markers, offering help or promises, asking questions or dodging, humbling, apologizing, stating clearly that the actions of the interlocutor are very valuable to the speaker and involve the speaker and the interlocutor in activities emerged twice. Meanwhile, focusing on the opposite person, intensifying the attention of the opposite speaker, avoiding conflict, adding or agreeing with the opposing speaker's opinion, assuming or displaying the same actions and stating indirectly and being optimistic emerged only once. In sum, 61 politeness strategies were used by Chon Wang including Bald-on record strategy (11), positive politeness strategy (33), negative politeness (10) and off-record politeness strategy (7).

For Roy O'Bannon, the highest politeness strategy is the bald-on record strategy (35), followed by paying more attention, giving recognition or sympathy to the interlocutor (14), determining agreement (8), being optimistic (7), paying attention to self versus speech and use group intimacy markers and humble themselves with each 6 times of usage. This is followed by asking questions or avoiding (5). Strategies to intensify attention to the interlocutor, avoid conflict, involve the speaker and interlocutor in the activity, and ask questions or dodge each of them appear 4 times. The bottom two with each appearing twice are joking strategy, offering help or promises, being pessimistic, reducing the burden of requests, apologizing and personalizing speakers and interlocutors. Whereas in the last place with each having 1 appearance is a strategy to equate assumptions into public opinion, apologize and personalize speakers and interlocutors. In sum, there are 120 uses of politeness strategies that include Bald-on record strategy (35), positive politeness strategy (63), negative politeness strategy (18) and off-record politeness strategy (5).

\section{Discussion}

\subsection{Bald-on Record Strategy}

The politeness strategy used is strongly influenced by their cultural background. The most intensively used strategy by Chon Wang and Roy O'Bannon is bald-on record strategy. However, Roy had more varied opponents than Chon. Roy used this strategy to anyone, 
anywhere and in any situation. Whereas Chon prefered to use this strategy for people who are close to him. An example of using a bald-on record strategy is in the example below:

$$
\text { Roy (RO67) }
$$

$$
\text { Help me lift some stuff up. }
$$

The sentence above is used by Roy to ask Chon for help in lifting goods. This sentence is categorized as bald-on record strategy because it is direct. If given to people who are already known, then the communication will be successful. Because Roy was a good friend of Chon, Chon immediately gave help to Roy.

$$
\text { Roy (RO78) }
$$

Stop! Put her down! C'mon put her down!

In contrast to the second example, the above sentence is used by Roy to ask a few unknown strangers to release Lin (Chon's younger sister) and not punish her. In this situation, Roy is also held captive so he cannot do much. Roy tried to give orders directly without further ado to people he did not know. As a result, the instructions were not heeded.

$$
\text { Chon }\left(\mathrm{CW}_{4}\right)
$$

\section{Reach for the sky! Reach for the sky!}

Unlike the two examples above, the third example is the words of Chon spoke to Roy when they first met. Chon put his index finger to Roy's back, as if Chon was pointing a gun at Roy's back. The aim is to surprise Roy. Roy had known Chon, so Roy didn't feel threatened. $\mathrm{He}$ understood that the one who did that was Chon from the Chon voice that he was familiar with. The words spoken by Chon to Roy belong to the bald-on record strategy category because they were used as efficiently as possible to get the attention of the other person.

Bald-on record strategy expressed by Roy is more varied than that of Chon. Roy gave that strategy to many people, both known and unknown. This is influenced by the culture he has. Roy is more expressive to everyone. As for Chon, he only did this strategy to people he knew. Chon did not do this strategy to people he did not know. This is influenced by the culture that Chon has. Chon isn't very open to people he doesn't know yet. In line with research finding by $\mathrm{Mu}$ (2015) which stated that western people are more direct, and tend to act spontaneously. While Chinese people usually emphasis on the uniformity or sameness, so they are less direct to new people.

\subsection{Positive politeness strategy}

Both characters in the Shanghai Knights film used a positive politeness strategy. The difference between the two is that Chon used a strategy of giving or asking for certain reasons as the highest strategy. There are two strategies that are not used by Chon, i.e the strategy of joking and the strategy of equating assumptions into public opinion. Whereas Roy uses a strategy of giving more attention, giving recognition or sympathy to the interlocutor as the most used strategy. Add or approve the opinions of the interlocutors and assume or display similarity in actions were not used. Here are some examples of positive politeness strategies: 


\title{
Chon (CW23)
}

Yeah. We're looking for my sister. She's staying at 32 Oxford Street.

Chon (CW28)

Why are you so mean to that boy?

The CW23 sentence was used by Chon to give reasons for the question raised by Charlie, a small child Chon met when he had just arrived in England. Charlie asked the reason Chon came to England. It was responded by Chon with $\mathrm{CW}_{23} 3$ sentence. Chon pointed out that he wanted to get closer to Charlie even though Charlie is an unknown person. Thus the speaker minimizes the FTA.

Chon used $\mathrm{CW}_{2} 8$ to ask Roy for reasons related to his attitude that seemed very rude to Charlie. Chon wanted to know because every time he communicated with Charlie, Roy always performed an FTA. Because Chon and Roy had a good relationship, the question aimed to minimize the distance between the speaker and the interlocutor. In other words, Chon expressed his attention and friendship to Roy, so Chon understood why Roy was so rude to Charlie.

For Roy, the highest usage of positive politeness strategy were giving more attention, giving recognition or sympathy to the interlocutor. Some examples of these strategies are given below:

\author{
Roy $\left(\mathrm{RO}_{5} 8\right)$ \\ What?! You're a maharaja. \\ That's Indian royalty.
}

The sentence appeared when Roy and Chon disguised themselves as guests of Jubilee Ball in search of the royal seal stolen by Lord Nelson Rathbone. In his disguise, Roy became Major General Sherlock Holmes and Chon as Maharaja of Nevada. Chon felt insecure about his disguise, yet Roy used $\mathrm{RO}_{5} 8$ to provide support and encouragement for Chon. That way Roy paid more attention to Chon that Chon was more confident. In line with Wardaugh (2006, p. 277) that positive politeness leads to achieve solidarity through the use of compliments, recognition or sympathy. This strategy is commonly used by people who have known each other fairly well like best friends.

All the examples above are categorized as positive politeness strategy. This strategy is aimed directly at the positive face of the speaker so that the wishes of the speaker are seen as a shared desire between the speakers. This strategy also functions as an accelerator of social relations with others.

In addition, Chon used many strategies to give or ask for certain reasons because in this film Chon tried to find the royal seal that had been stolen. Chon used the question and answer strategy to get as much information as possible about the royal seal's whereabouts. Chon was impressed to be very persistent and seriously looking for it. This can illustrate Chinese culture which emphasizes family values, that respect for the family is very important. For Chon, finding the royal seal is his responsibility to safeguard the honor of his family. 


\subsection{Negative politeness strategy}

There are several negative politeness strategies that Chon uses including asking questions or avoiding, humbling, apologizing and stating clearly that the actions of the interlocutor are very valuable to the speaker. The strategies of reducing the burden of requests, personalizing speakers and interlocutors, puts threatening actions as a general rule and nominalization were not used by Chon in this film. For Roy, the strategy that is frequently used is self-humility. The strategy implies indirectly, nominalization and states clearly that the actions of the interlocutor are very valuable to the speaker appear in the dialogue put forward by Roy. Below are a few examples of using the negative politeness strategy spoken by Chon and Roy:

$$
\text { Chon (CW47) }
$$

I'm sorry that I hurt you.

$$
\text { Roy ( } \left.\mathrm{RO}_{23}\right)
$$

You've got a sense of purpose. But look at me.

I'm a 30 year-old waiter. Where's the future in that?

The CW47 sentence is the sentence Chon used to apologize because Chon had hurt Roy's heart. Chon forbade Lin to deal with Roy. Chon said bad things about Roy to Lin to keep Lin away from Roy. Roy found out about it. This made Roy angry with Chon. The CW47 sentence is a sentence of apology Chon said to Roy as well as showing remorse. While the sentence $\mathrm{RO}_{23}$ is a sentence spoken by Roy when he humbled himself before Chon. Roy now works as a waiter in a hotel, the book he wrote is not very successful in the market and Chon is a Sheriff in Nevada. On that basis Roy considers Chon more successful than himself.

A negative politeness strategy is an action taken to make up for the negative face of the speaker and the desire of the speaker to be free from the burden with the intention that the actions and intent are not disturbed and not constrained. The above example is a strategy of apologizing and humbling yourself. This action is nothing but done because most likely the speaker gives a burden or disturbance to the interlocutor before.

The use of an apology strategy by Chon illustrates Chinese culture which upholds one's honor. If someone makes a mistake, then he will not be ashamed to admit mistakes and apologize. Actually all cultures do the same thing. However, in Chinese culture, these norms are more emphasized. Chinese culture concern more on social hierarchy and norms that apply in the society (Pramujiono, 2012). Western people tends to be more individualist. It is sometimes said that individualist cultures focus on I. They have their own criteria of success in the society (Leech, 2007). Roy, who has a western cultural background, emphasizes the success of individuals in society. In this case, he felt unsuccessful so he felt inferior.

\subsection{Off-record Politeness Strategy}

Chon uses more off-record politeness strategies compared to Roy. This strategy is realized in a disguised way and does not represent a clear communicative purpose. With off-record 
strategy, the speakers let the interlocutors interpret the intention of the message (Brown \& Levinson, 1987, p. 211).

$$
\text { Chon (CW38) }
$$

Our father would talk about the right man for you.

Not like Roy. He has many bad habits.

$$
\text { Roy }(\mathrm{RO} 18)
$$

I have one word for you. Zeppelin.

In the $\mathrm{CW}_{3} 8$ example, Chon said something about Roy but seemed to underestimate Roy, thinking Roy was not good enough for his younger sister. He did not give more explainations which made more questions to the opponent. In the RO18 example, Roy gave incomplete information which makes Chon curious. Both of these examples are the use of off-record politeness strategies. Then why did Chon use off-record politeness strategies more often than Roy? This could be influenced by the cultural background of the two. Chinese culture tends to be a bit closed and not too open to express something whereas in western culture, people are very open and spontaneous. The reason is reflected in the use of strategies used by Chon and Roy.

\section{Conclusion}

From the discussion presented, the writer can prove that all the strategies initiated by Brown and Levinson (1987) were applied by two main characters of Shanghai Knights, Chon Wang (CW) and Roy O'Bannon (RO). The strategies include (1) Bald-on Record Strategy (without strategy), (2) Positive politeness strategy, (3) Negative politeness strategy and (4) Off -record politeness strategy (indirect or disguised strategy). Chon Wang used a total of 61 politeness strategies with the frequency of 11 for Bald-on record strategies, 33 for positive politeness strategies, 10 for negative politeness strategies and 7 for off-record politeness strategies. In the Shanghai Knights film, Roy O'Bannon used 120 politeness strategies with 35 uses for Bald-on record strategy, 63 for positive politeness strategy, 18 for negative politeness strategy and 5 for off-record politeness strategy.

The politeness strategy used is strongly influenced by cultural background. The strategy used most often by Chon Wang and Roy O'Bannon bald-on record strategy. But Roy has more varied opponents than Chon. Roy used this strategy to anyone, anywhere and in any situation. Whereas Chon preferred to use this strategy for people who are really close.

Off-record politeness strategy is the strategy that is least used by both. Chon uses offrecord politeness strategies more frequently than Roy. This happens because the influence of Chinese culture tends to be a bit closed and not too open to express something. Whereas in western culture, people are very open and spontaneous so Off-record politeness strategy is not frequently used.

This suggests that an understanding of politeness strategies is needed to realize facethreatening actions (FTA). In other words, politeness strategies are used to maintain continuity and success in communicating Politeness strategy teaches how to use the language in order to have a conversation goes well and runs smoothly. In addition, people do not want to lose face while communicating. The face is something that is emotionally 
implanted, nurtured, enhanced, and constantly attended in an interaction (Aditiawarman \& Elba, 2018). The use of politeness strategies among two people with different cultural background need to be addressed as a diversity that the interactants need to understand each other so that communication can take place in harmony (Pramujiono, 2012). That is why there was no conflict occurs due to the use of politeness strategies in Shanghai Knights movie because of the reasons above.

This research still has many weaknesses. Still limited to the politeness strategies used by characters and analyse them from the perspective of cultural background of the speakers. The writer suggests that the next researchers use other theories in Pragmatic. The next researcher can also conduct a research on the politeness strategies in its semantic feature or elaborate it with another field of study such as the critical discourse analysis to make this study more complete.

\section{References}

Aditiawarman, M., \& Elba, R. P. (2018). The Politeness Strategies Used in The Movie The Chronicles of Narnia. Jurnal Ilmiah Langue and Parole, 2(1), 32-38. https://doi.org/10.36057/jilp.v2i1.331

Aryanto, W. J. (2014). A Study of Politeness Strategies Used By the Characters of the Ugly Truth Movie. Faculty of Culture Studies - Universitas Brawijaya.

Brown, P., \& Levinson, S. C. (1987). Politeness: Some Universal in Language Usage. Cambridge: Cambridge University Press.

Chaer, A., \& Agustina, L. (1995). Sosiolinguistik Perkenalan Awal. Rineka Cipta.

Eelen, G. (2001). Kritik Teori Kesantunan (Jumadi dan Slamet Rianto, terj.). Surabaya: Airlangga University Press.

Fitriah., \& Hidayat, D. N. (2018). Politeness: Cultural Dimensions of Linguistic Choice. IJEE, 5(May), 26-34. https://doi.org/10.15408/ijee.v5i1.IJEE

Heryadi, H., \& Silvana, H. (2013). Komunikasi Antarbudaya Dalam Masyarakat Multikultur. Jurnal Kajian Komunikasi, 1(1).

Hofstede, G. (2001). Culture's consequences: Comparing values, behaviors, institutions and organizations across nations (2nd ed.). Sage Publications.

Keraf, G. (1997). Komposisi: Sebuah Pengantar Kemahiran Bahasa. Ende-FLores: Penerbit Nusa Indah.

Leech, G. (2007). Politeness: Is there an East-West divide? Journal of Politeness Research Language, Behaviour, Culture, 3(2), 167-2016, ISSN $1613-4877$.

Levinson, S. C. (1983). Pragmatics. Cambridge: Cambridge University Press.

Lucky Nur Safitri, F., Mujiono, \& Herawati, S. (2015). A Study on Politeness Strategies of Characters in The big Wedding Movie Directed by Justin Zackham. Jurnal Ilmiah Bahasa Dan Sastra, 2(2).

Miles, M., \& Huberman, A. (1994). Qualitative Data Analysis: An Expanded Sourcebook. California: SAGE Publications.

Mu, Y. (2015). The Application of Politeness Strategies in English and Chinese Movie Reviews. International Journal of English Linguistics, 5(6), 105. https://doi.org/10.5539/ijel.v5n6p105

Mustiari, N., Tika, I., \& Widiastuti, N. (2017). Politeness Strategies in Delivering Commands in the Movie Entitled "The Social Network." Humanis, 19(1), 268-274. 
Pradnyani, N., Budiarsa, M., \& Sudana, I. (2017). Positive Politeness Strategies in Animation Movie "Home" Directed By Tim Johnson. Jurnal Humanis, 19(1), 198-205.

Pramujiono, A. (2012). Dari Mianzi Dan Lian Menuju Face: Dari Kearifan Lokal Cina Menuju Teori Kesantunan Yang Mendunia. Lingua Cultura, 6(2), 200. https://doi.org/10.21512/lc.v6i2.407

Pratiwi, E. ., Santihastuti, A., \& Sukmaantara, I. P. (2018). Brown and Levinson's Politeness Strategies on Apologizing Expression of "The Princess Diaries" (2001) The Movie: A Discourse Analysis. Jurnal Edukasi, 5(1), 24. https://doi.org/10.19184/jukasi.v5i1.8013

Retnowaty, R. (2015). Politeness Strategies Used by Colter Stevens as the Main Character in Source Code Movie. 4th English Language Teaching Literature and Translation, May. https://www.researchgate.net/publication/316655793_Politeness_Strategies_Used_b y_Colter_Stevens_as_the_Main_Character_in_Source_Code_Movie

Rosari, M. (2016). Politeness Strategies Applied by the Characters of The Great Debaters Movie. Language and Language Teaching Journal, 19(01), 19-33. https://doi.org/10.24071/llt.2016.190103

Sari, K., Sili, S., \& Setyowati, R. (2017). Politeness Strategies Used By the Characters In Finding Neverland Movie ( 2004 ). Jurnal Ilmu Budaya, 1(4), 377-388.

Selfia, M., \& Marlina, L. (2016). An Analysis of Politeness Strategies Used By Deddy Corbuzier in Hitam Putih Talk Show. Journal UNP, 5(1), 43-48.

Supriyanta, S., Language, I. G.-J. (Journal of E., \& 2017, U. (2017). An Analysis of Politeness Strategies Used by Claire Peterson in the Boy Next Door Movie. Jurnal.Ustjogja.Ac.Id. https://jurnal.ustjogja.ac.id/index.php/JELLT/article/view/921

Suryani Christina, S. C. \& R. D. (2018). An Analysis of Politeness Strategies Used by The Characters in The Blind Side Movie. 2(4), 1-8.

Syamsuddin, A. (1996). Sanggar Bahasa Indonesia. Jakarta: Universitar Terbuka.

Tian, X., \& Zhao, H. (2006). On Specificity of Politeness-Contrastive Study of Western and Chinese Concepts of Politeness. Sino-US English Teaching, 3(2), ISSN 1539-8072.

Ulfa, N. (2019). Politeness Strategies and Cooperation Principle in "Wonder" Movie. International Journal for Innovation Education and Research, 7(7), 563-573. https://doi.org/10.31686/ijier.vol7.iss7.1596

Wardaugh, R. (2006). An Introduction to Sociolinguistics. Wiley Blackwell.

Wierzbicka, A. (2003). Cross-Cultural Pragmatics The Semantic of Human Interaction. Berlin: Mouton de Gruyter.

Yule, G. (1996). Pragmatics. Oxford: Oxford University Press. 